\title{
THE EFFECT OF PENTAGONAL AND OCTAGONAL JOINT DESIGN ON THE FATIGUE STRENGTH OF POLYMER-MATRIX COMPOSITE MATERIALS
}

\author{
VPLIV PETEROKOTNE IN OSMEROKOTNE OBLIKE SPOJEV NA \\ TRAJNO NIHAJNO TRDNOST KOMPOZITNIH MATERIALOV S \\ POLIMERNO MATRICO
}

\author{
Cigdem Ersan ${ }^{1}$, Olcay Ersel Canyurt ${ }^{2 *}$ \\ ${ }^{1}$ Pamukkale University, Engineering Faculty, Kinikli Mah. University Road No. 11, Pamukkale, 20160 Denizli, Turkey \\ ${ }^{2}$ Gazi University, Engineering Faculty, Eti. Mah. Yukselis Sok. No. 5, 06570, Maltepe, Ankaara, Turkey \\ Prejem rokopisa - received: 2018-09-05; sprejem za objavo - accepted for publication: 2019-03-27
}

doi:10.17222/mit.2018.193

\begin{abstract}
Joining methods and suitable geometry selection become an important role in the bonding of composites. The fatigue strength of adhesively bonded joint of thick woven type laminated E-glass/ Polymer matrix composites consist of 22 layers with a layer thickness of $0.5 \mathrm{~mm}$ was investigated experimentally. Frequency was kept constant at $10 \mathrm{~Hz}$ for all experiments, while the load ratio was equal to 0.1 , resulting in a tension-tension fatigue loading. Octagonal and pentagonal tongue and groove joint design were used in order to join thick composite materials. Experimental results and SEM analysis of present study indicated that fatigue strength was strongly influenced by the geometry of joint design. Claw length and claw width defined in the design were found to have a significant effect on fatigue strength of adhesively bonded joints. The octagonal design showed almost two times higher fatigue strength than pentagonal joint design.
\end{abstract}

Keywords: polymer matrix composites, fatigue strength, thick composites, tongue joint design, groove joint design

Primerna izbira metode spajanja in ustrezna geometrija spoja igrata pomembno vlogo pri spajanju kompozitov. Avtorji so eksperimentalno določali trajno nihajno trdnost adhezivno z lepili vezanih spojev iz tkanih debelih laminiranih kompozitov s polimerno matrico in ojačitvijo iz steklenih vlaken tipa E. Kompoziti so bili sestavljeni iz 22 plasti in pri tem je bila vsaka plast debela $0,5 \mathrm{~mm}$. Pri vseh preizkusih so spoje utrujali v natezno-nateznem načinu obremenjevanja, izbrano razmerje obremenitev je bilo 0,1 in frekvenca utrujanja je bila $10 \mathrm{~Hz}$. Za spajanje izbranih kompozitnih materialov so izbrali peterokotne in osmerokotne jezične in utorovne oblike spoja. Eksperimentalni rezultati in SEM-analize te študije so pokazali, da je trajna nihajna trdnost spojev močno odvisna od njihove geometrije oz. oblike. Ugotovili so, da dolžina in širina čeljusti pomembno vplivata na trajno nihajno trdnost adhezivno vezanih spojev. Osmerokotna oblika je imela skoraj dvakrat višjo trajno nihajno trdnost kot peterokotna oblika spoja.

Ključne besede: kompoziti s polimerno matrico, trajna nihajna trdnost, debeli kompoziti, jezična oblika spoja, utorovna oblika spoja

\section{INTRODUCTION}

The fatigue strength of thick composite materials, which are preferred due to lightness, and high strength, is influenced by many factors, such as geometry, material of joining part, adhesive material, etc. The importance of the joining methods using adhesives is increasing in the field of manufacturing due to the having many advantages compared with other joining methods. Composite materials are widely used in aerospace, automotive, ship structures and other structures. Many researches were performed in order to understand the joint behavior of the composite materials. Technological development was revealed to join different materials together such as metal, plastic, composite etc.

Nowadays, adhesive joints quite improved mechanical properties (shear/tensile strength, shear/peel strength, impact and shock resistance) have been used instead of

*Corresponding author's e-mail:

canyurt@gazi.edu.tr (Olcay Ersel Canyurt) mechanical fastening methods. Strong structures require quality adhesion techniques. Bonding strength can be increased with increasing chemical properties of adhesives as well as using quality joining technique. The performance of the joint strength could be increased with the joint design of the adherend.

Adhesive bonding techniques of inclined and stepped joint configuration along the thickness have been used in the literature for thick composites. Tongue and Groove (T\&G), high strength glued connections was first investigated by the American Navy General and Rensselaer Polytechnic Institute, New York, USA. The effect of tongue length, lateral tension, strength and the shear stress distributions formed on the adhesion surface were examined in case of static loading. $T \& G$ technique was showed more efficient than the other techniques. ${ }^{1}$ Nine different geometric shapes of $\mathrm{T} \& \mathrm{G}$ type connection carbon/epoxy composite material and stainless steel were inspected experimentally. Considering the same adhesion length, the strap connection type and $T \& G$ connection 
were compared and it was stated that the connections with all type of geometries for $\mathrm{T} \& \mathrm{G}$ type connection were stronger. ${ }^{2}$ The adhesive bonding of glass fabric/ vinyl ester materials and steel plate materials by $T \& G$ method were analyzed by finite element method (FEM). Scaling of elastic results according to plate thickness, shows that the stresses supported by the adhesive for certain total stress levels given to the adhesive plate were not dependent on the plate thickness. ${ }^{3}$ The mechanical properties of bonded joints between rotational parts were identified using FEM using ABAQUS and compared with experimental results in order to improve the joint design for industry. ${ }^{4}$ The pre-stress effect, which could be applied in these connections, was described in literature. ${ }^{5}$ Since the lateral pre-stress reduced the peeling stresses, consequently the adhesive bonding could withstand higher tensile forces. Attempts have been made to reduce the peeling stress in the thick composite materials considering by the effect of geometry on the adherend and temperature. Experimental results indicated that type the angle of adhesion surface significantly increased the fatigue strength. ${ }^{6}$ Finite element analysis program was used to correlate the geometric parameters, interfacial peeling stress and the Von Misses stress within the adhesive. ${ }^{7}$ Six different composites were produced using fibers in different proportions to investigate the mechanical properties of natural fiber filled with fiber glass reinforced polymer composite. The failure was identified with SEM analysis. ${ }^{8}$ The adhesive strength of polymer materials was influenced by pretreatment and temperatures. ${ }^{9}$ Crack initiation and damage evolution in adhesively bonded joints under different loading such as cyclic, tension/compression and shear were analyzed to optimize the design for high-tech applications. The mechanical behavior of adhesively bonded joints under cyclic loadings was quite complex. Loading parameters such tensile/compression-shear loads, mean load and load amplitude could influence the crack initiation life. ${ }^{10}$ Geometrical parameters considered

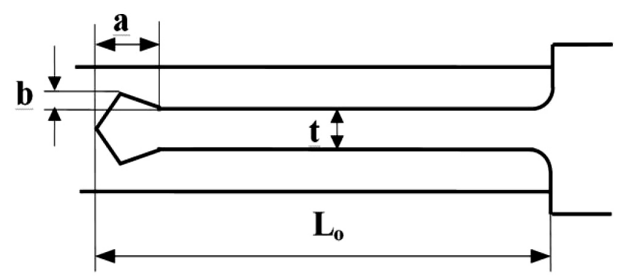

a)

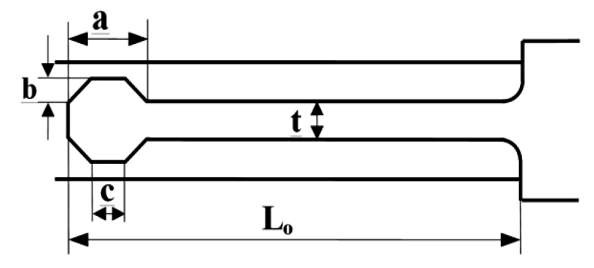

b)

Figure 1: a) Pentagonal b) octagonal designs with applied parameters in the experiment showed that parameters influenced the fatigue strength. ${ }^{11}$ The behavior of the tongue/groove adhesive bonding was found by the genetic algorithm. The experimental and model results indicated that bonding strength depend on factors such as bonding length/thickness and pre-stress. ${ }^{12}$ The fatigue behavior of layered thick woven composites was examined with nonlinear GA model and experimental results. Optimum design parameters were determined to obtain a strong adhesively bonded connection. ${ }^{13}$

In this study, the tongue and groove joint of thick woven layered polymer matrix composite materials with special tip designs were considered. Two type tips such as pentagonal and octagonal design were constituted and fatigue behaviours of these two designs were investigated experimentally. The stronger tip design on the joint using optimum design parameters was discovered under dynamic loading.

\section{MATERIAL AND METHOD}

Experiments were carried out in the composite laboratory of the Mechanical Engineering Department at Pamukkale University. E-glass/ Polymer matrix composites, Polires 840, consist of 22 layers with a layer thickness of $0.5 \mathrm{~mm}$ was used in the experiments. The specimens bonded with Loctite-Hysol 9466 epoxy were cured at room temperature for one week specified by the manufacturer. All fatigue tests were performed on an Instron 8801uni-axial universal dynamic servo hydraulic materials testing system with capacity of $50 \mathrm{kN}$. Two different geometric types, which are pentagonal and octagonal, designs were used in this study. Both design shown in Figure 1, were studied parametrically.

The total tongue lengths, denoted as $L_{0}$, and the tongue widths denoted as $t$ was taken equal for all specimens and variable parameters were determined for the designed profiles. Two parameters $(\mathrm{a}, \mathrm{b})$ were considered for pentagonal design octagonal design. The parameter $a$ and $b$ considered as claw length and thickness, respectively. Parameter $c$ was taken as $6 \mathrm{~mm}$ for octagonal designs. The gap which is adhesive thickness between tongue and grove was considered as $0.2 \mathrm{~mm}$ which supplies the strong joint configuration..$^{9,11}$

\section{EXPERIMENTAL RESULTS AND DISCUSSIONS}

\subsection{Determination of load amplitude and mean load}

The influence of tensile-tensile fatigue loadings on the cyclic behavior of adhesively bonded $T \& G$ joints with different tip geometry was analyzed in this part. Frequency and the load ratio $(\mathrm{R})$ were kept constant at $10 \mathrm{~Hz}$ and 0.1 for all experiments using sinusoidal wave form was generated to see the fatigue behavior of both designs and to determine pre-defined load for parametric study. 


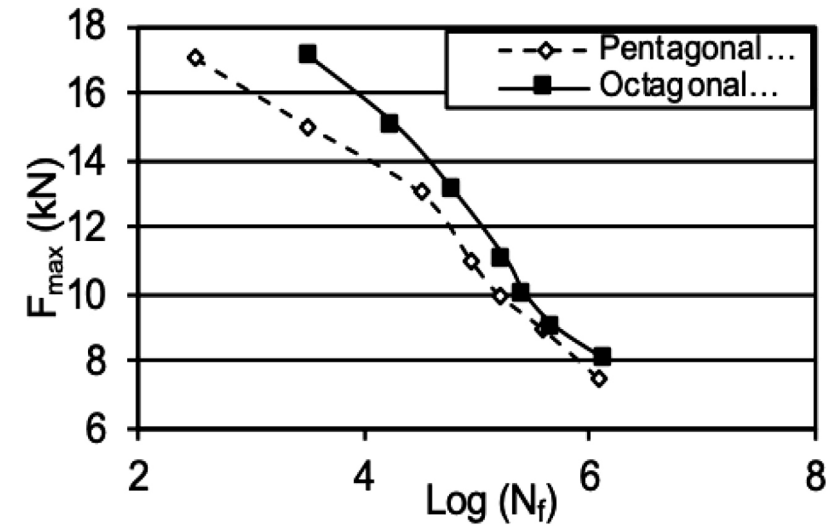

Figure 2: $F_{\max }-\log \left(N_{\mathrm{f}}\right)$ graph for pentagonal and octagonal design

Tests were performed applying different load amplitudes and mean loads until the failure. The influence of maximum load $\left(F_{\max }\right)$ versus number of cycles at failure $\left(N_{\mathrm{f}}\right)$ can be seen in Figure 2. $F_{\max }-\log \left(N_{\mathrm{f}}\right)$ graph for pentagonal and octagonal design shows the fatigue behavior of both designs. Pentagonal and octagonal joint failed at 321 and 3350 cycles for $F_{\max }=17 \mathrm{kN}, 88900$ and 176815 cycles for $F_{\max }=11 \mathrm{kN}, 375000$ and 481645 cycles for $F_{\max }=9 \mathrm{kN}$. The results stated that octagonal design in the joint region has stronger joint configuration compared with pentagonal design.

Selecting $F_{\max }=8 \mathrm{kN}$ and under this load have a very long fatigue life, exceeding 1 million cycles. Pre-defined maximum load was preferred as $11.00 \mathrm{kN}$ in order to examine geometry effect. The fatigue test conditions in the current study are presented in Table $\mathbf{1 .}$

Table 1: Fatigue test conditions

\begin{tabular}{|c|c|c|c|c|c|}
\hline$R$ & $\begin{array}{c}\text { Frequency } \\
(\mathrm{Hz})\end{array}$ & $\begin{array}{c}F_{\max } \\
(\mathrm{kN})\end{array}$ & $\begin{array}{c}F_{\min } \\
(\mathrm{kN})\end{array}$ & $\begin{array}{c}F_{\text {ave }} \\
(\mathrm{kN})\end{array}$ & $\begin{array}{c}F_{\text {amplitude }} \\
(\mathrm{kN})\end{array}$ \\
\hline 0,1 & 10 & 11,00 & 1,10 & 6,05 & 4,95 \\
\hline
\end{tabular}

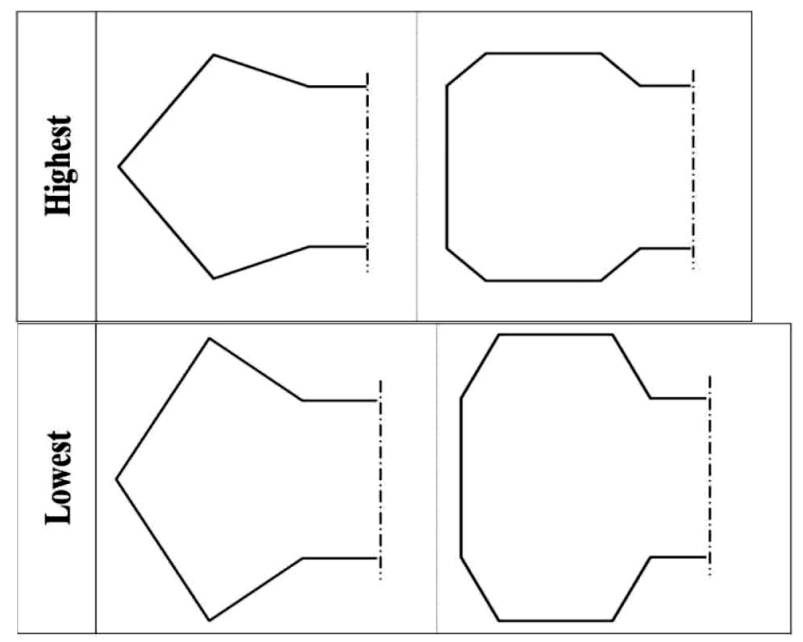

Figure 3: The tip geometries created with parameters showing the highest $(b=2 \mathrm{~mm})$ and lowest $(b=4 \mathrm{~mm})$ fatigue values for $a=$ $10 \mathrm{~mm}$

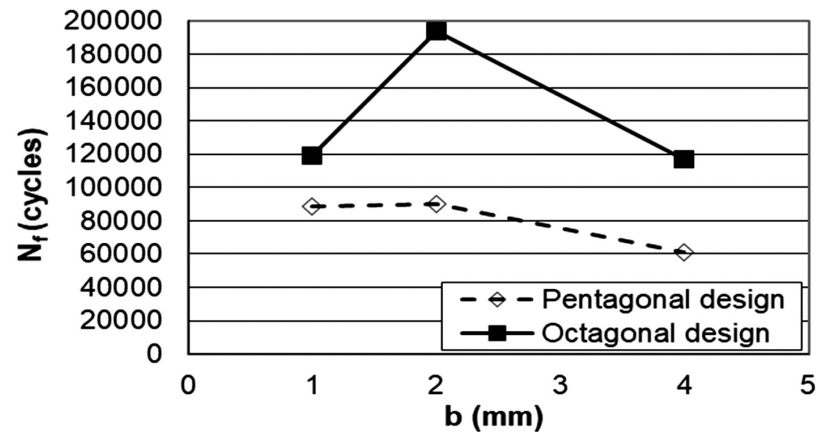

Figure 4: Comparison of $N_{\mathrm{f}}$ values according to parameter $b$ for pentagonal and octagonal design while $a=10 \mathrm{~mm}$

\subsection{Evaluation of joint design}

Two basic $T \& G$ joint configuration such pentagonal design and octagonal design were tested and analyzed by longitudinal fatigue loading. Parameters of claw length and thickness $(a, b)$ were considered for pentagonal design and octagonal design.

The first configuration of claw length of $10 \mathrm{~mm}$, appearing in Figure 3 indicated that the claw thickness strongly influenced the fatigue failure.

Optimum claw lengths exist for both designs. An increment of claw thickness from $1 \mathrm{~mm}$ to $2 \mathrm{~mm}$ resulted in $62 \%$ and $2 \%$ increase for octagonal design and pentagonal design, respectively. After optimum claw thickness, an increment of claw thickness from $2 \mathrm{~mm}$ to $4 \mathrm{~mm}$ resulted in $39 \%$ and $32 \%$ decrease. The lowest strength was seen at the highest claw thickness parameter. Attenuation of the claw weakened the joint strength. Wide claw structure that led to squeeze the head of the tongue part and peel off the groove part was easily crushed under fatigue loading. Octagonal design showed good performance compared with pentagonal design as shown in Figure 4. Fatigue strength for best configuration of octagonal design was observed $114 \%$ higher than best configuration of pentagonal design.

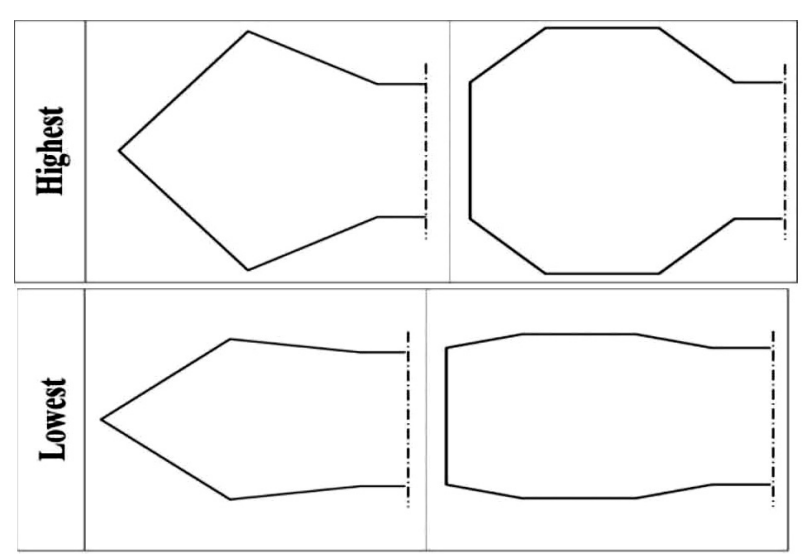

Figure 5: The tip geometry created with parameters showing the highest $(b=4 \mathrm{~mm})$ and lowest $(b=1 \mathrm{~mm})$ fatigue values for $a=$ $14 \mathrm{~mm}$ 
C. ERSAN, O. E. CANYURT: THE EFFECT OF PENTAGONAL AND OCTAGONAL JOINT DESIGN ...

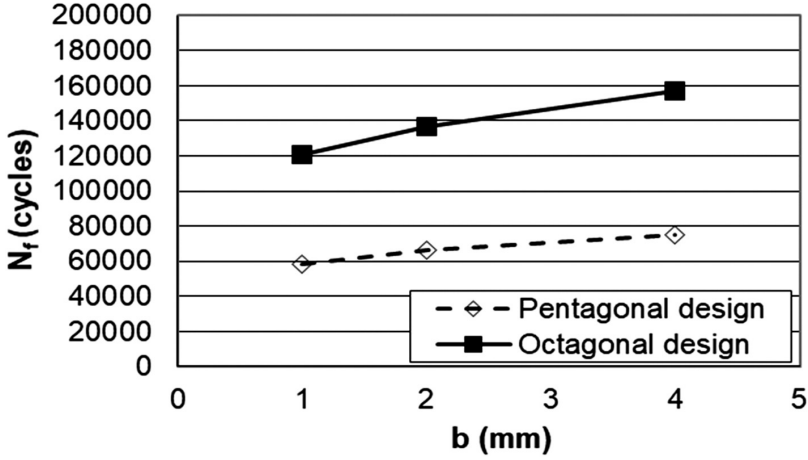

Figure 6: Comparison of $N_{\mathrm{f}}$ values according to parameter $b$ for pentagonal and octagonal design while $a=14 \mathrm{~mm}$

The second configuration of claw length of $14 \mathrm{~mm}$, shown in Figure 5 stated that an increment of claw thickness resulted an increase in number of fatigue failure for both designs.

Claw thickness increment resulted in $13 \%$ and $25 \%$ increase for both designs compared with $2 \mathrm{~mm}$ and $4 \mathrm{~mm}$ with $1 \mathrm{~mm}$ thickness. Octagonal design for all configurations was observed $105 \%$ higher than pentagonal design, Figure 6.

The last configuration of claw length of $18 \mathrm{~mm}$ indicated that claw thickness did not influence the fatigue strength for both designs. Fatigue strength for best configuration of octagonal design was found $96 \%$

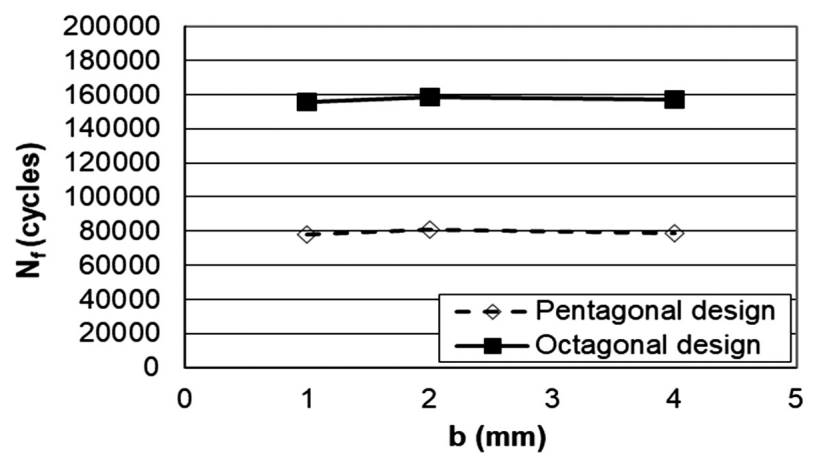

Figure 7: Comparison of $N_{\mathrm{f}}$ values according to parameter $b$ for pentagonal and octagonal design while $a=18 \mathrm{~mm}$

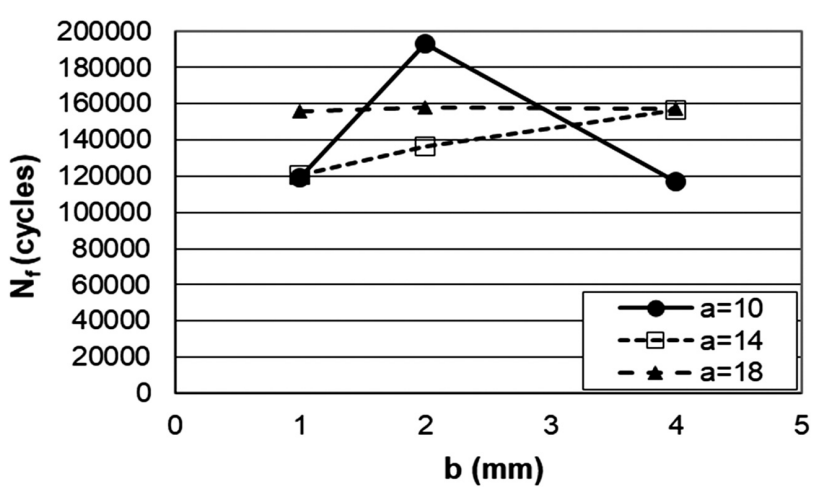

Figure 8: Comparison of $N_{\mathrm{f}}$ values according to parameter $a$ and $b$ for octagonal design

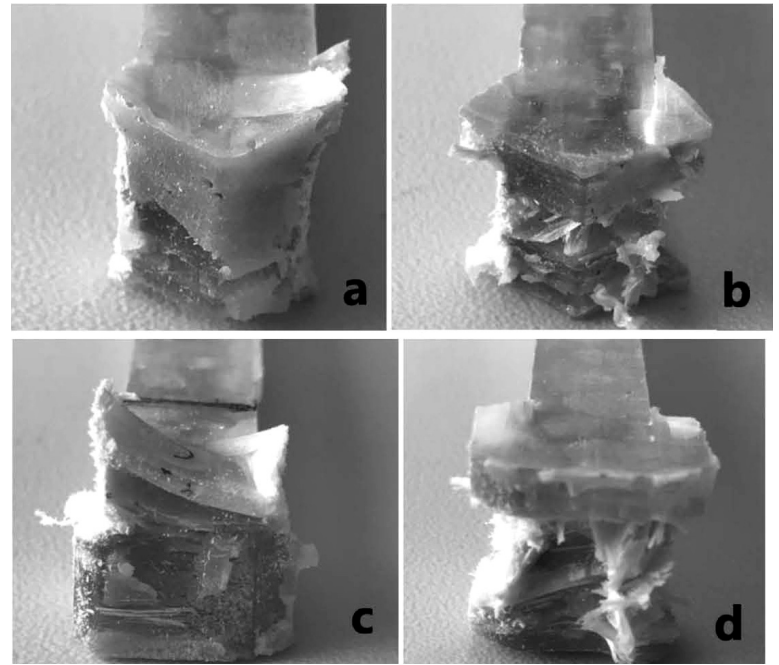

Figure 9: Damaged region: a) strongest pentagonal tip, b) weakest pentagonal tip, c) strongest octagonal tip, d) weakest octagonal tip

higher than best configuration of pentagonal design, Figure 7. Both design demonstrated the same trend according to the design parameters.

Pentagonal design showed weaker fatigue strength properties for all values of claw length and thickness. The comparison of octagonal design for claw length and thickness was presented in Figure 8.
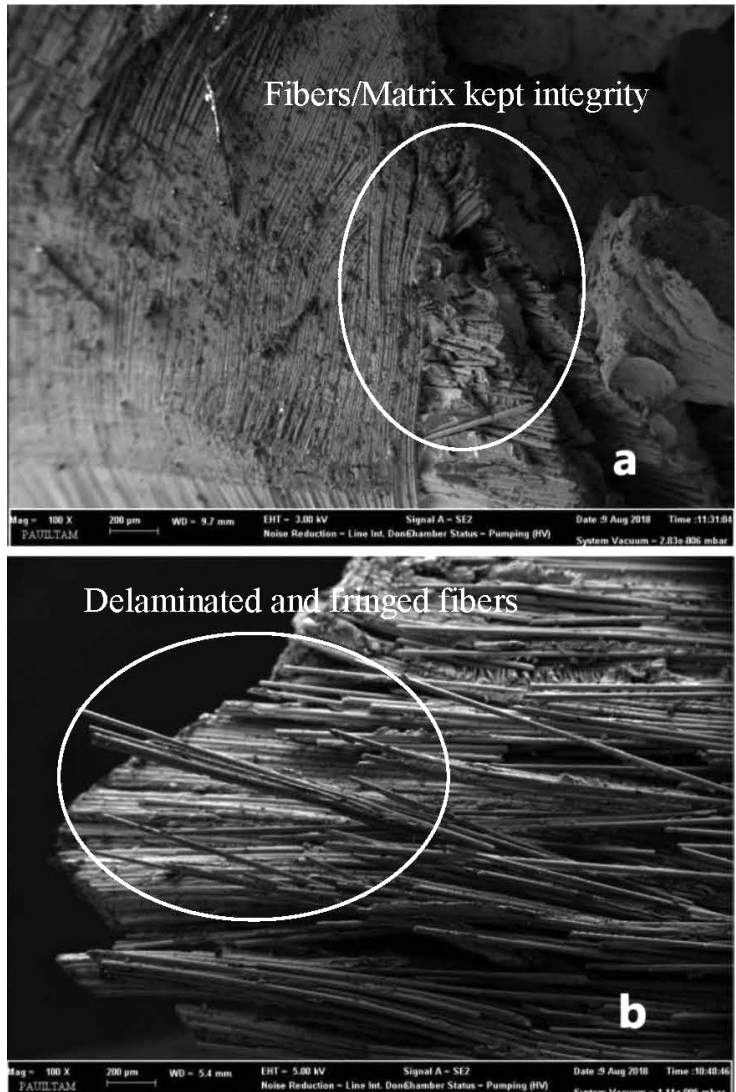

Figure 10: SEM images of: a) strongest and b) weakest pentagonal design 

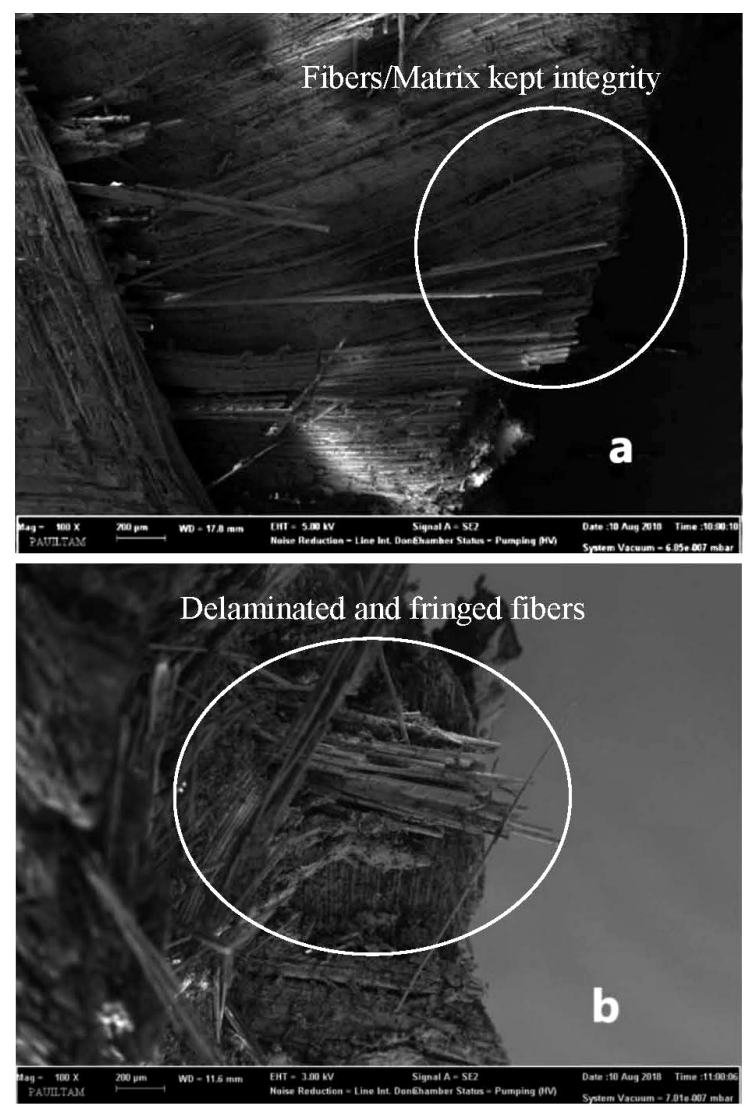

Figure 11: SEM images of a) strongest and b) weakest octagonal design

The appropriate claw length and thickness combination exhibited a stable joint structure and an increase on the joint strength for adhesively bonded thick composite laminates.

\subsection{Scanning electron microscope (SEM) analysis}

The specimens were initially coated by gold using Quorum 150R ES device and examined using ZEISS SUPRA 40VP scanning electron microscope. The failure region of the most durable and weakest specimens of pentagonal and octagonal tips were shown in Figure 9.

Morphological studies using a SEM evidently illustrate the failure of the fiber and matrices at the damage region. The damage regions of pentagonal and octagonal tips show different fracture zones. Although, the matrix polymer did not dissolve so much and the fibers did not disperse in the damage regions for the strong tip designs, the fiber filaments and matrix material were delaminated and dispersed from each other for the weakest tip designs. The strongest and weakest pentagonal tip designs were shown in Figure 10.

Fibers and matrix kept their integrity in the strong octagonal tip design. Fibers were delaminated and fringed in the damage regions, while polymer matrix was scattered for the weakest octagonal tip design shown in Figure 11.

Comparing SEM images between the pentagonal and octagonal designs, it appeared that the octagonal design maintained the integrity of the fibers and matrix exist less separation between layers in the damage regions. Therefore, octagonal designs showed higher strength values compared with pentagonal designs. This circumstances indicated that the bonding geometry and polymer matrix and glass fiber interface are important for better mechanical properties of the composites.

\section{CONCLUSIONS}

A series of fatigue loading was performed on specimens consisting two types of bonding design for thick sandwich glass composite materials. The results suggested that octagonal design tongue and groove joints provided superior strength in adhesively bonded thick composite connections under dynamic loading. In particular, the octagonal design with claw length of 10 mm and claw thickness of $2 \mathrm{~mm}$ supported about 193509 cycles under $11 \mathrm{kN}$ maximum load and load ratio of 0.1 . Fatigue strength could exceed millions of cycles under 8 $\mathrm{kN}$. Experimental results indicated that claw length and claw width have a strong influence on the fatigue strength of adhesively bonded joints. Octagonal design demonstrated better performance compared with pentagonal for all conditions. Fatigue strength for best configuration of octagonal design was obtained 2.14 times higher than best configuration of pentagonal design. The bonding geometry and polymer matrix and glass fiber interface strongly influenced the mechanical properties of the adhesively bonded composites.

\section{Acknowledgement}

This study was supported by the Unit of Scientific Research Projects (USRP) of Pamukkale University. Project number is 2014FBE039. The authors would express their thanks to Pamukkale University for their kind supports.

\section{REFERENCES}

${ }^{1}$ G. Dvorak, J. Zhang, O. E. Canyurt, Adhesive tongue-and-groove joints for thick composite laminates, Compos. Sci. Tech., 61 (2001) 1123-1142, doi:10.1016/S0266-3538(01)00012-4

${ }^{2}$ J. D. Melogranaa, J. L. Grenestedt, W. J. Maroun, Adhesive tongueand-groove joints between thin carbon fiber laminates and steel, Composites Part A, 34 (2003) 119-124, doi:10.1016/S1359835X(03)00005-8

${ }^{3}$ K. Matous, G. J. Dvorak, Analysis of tongue and groove joints for thick laminates, Composites Part B, 35 (2004) 609-617, doi:10.1016/j.compositesb.2004.01.006

${ }^{4}$ P. Bernardin, J. Vacik, T. Kroupa, R. Kottner, Determination of the mechanical parameters of a bonded joint between a metal and a composite by comparing experiments with a finite-element model, Mater. Tehnol., 47 (2013) 417-421 


\section{ERSAN, O. E. CANYURT: THE EFFECT OF PENTAGONAL AND OCTAGONAL JOINT DESIGN ...}

${ }^{5}$ O. E. Canyurt, J. Zhang, Pre-stressed adhesive strap joints for thick composite sandwich structures, Int. J. Mech. Sci., 48 (2006) 389-399, doi:10.1016/j.ijmecsci.2005.11.004

${ }^{6}$ L. F. M. Da Silva, R. D. Adams, Techniques to reduce the peel stresses in adhesive joints with composites, Int. J. Adhes. Adhes., 27 (2007) 227-235, doi:10.1016/j.ijadhadh.2006.04.001

${ }^{7}$ Y. M. Jen, Fatigue life evaluation of adhesively bonded scarf joints Int. J. Fatigue, 36 (2012) 30-39, doi:10.1016/j.ijfatigue.2011.08.018

${ }^{8}$ M. Annamalai, R. Ramasubbu, Optimizing the formulation of e-glass fiber and cotton shell particles hybrid composites for their mechanical behavior by mixture design analysis, Mater. Tehnol., 52 (2018) 207-214, doi:10.17222/mit.2017.119

${ }^{9}$ S. Kaner, T. Sekercioglu, Effect of surface pre-treatments and ageing on the adhesive strength of polymer joints, Polymer (Korea), 41 (2017) 827-834, doi: 10.7317/pk.2017.41.5.827
${ }^{10}$ D. Thevenet, R. Créachcadec, L. Sohier, J.Y. Cognard, Experimental analysis of the behavior of adhesively bonded joints under tensile/compression-shear cyclic loadings, Int. J. Adhes. Adhes., 44 (2013) 15-25, doi:10.1016/j.ijadhadh.2013.01.011

${ }^{11}$ J. H. Tang, I. Sridhar, N. Srikanth, Static and fatigue failure analysis of adhesively bonded thick composite single lap joints, Compos. Sci. Tech., 86 (2013) 18-25, doi:10.1016/j.compscitech.2013.06.018

${ }^{12}$ O. E. Canyurt, C. Meran, M. Uslu, Strength estimation of adhesively bonded tongue and groove joint of thick composite sandwich structures using genetic algorithm approach, Int. J. Adhes. Adhes., 30 (2010) 281-287, doi:10.1016/j.ijadhadh.2009.09.005

${ }^{13}$ O. E. Canyurt, C. Meran, Fatigue strength estimation of adhesively bonded tongue and groove joint of thick woven composite sandwich structures using genetic algorithm approach, Int. J. Adhes. Adhes., 33 (2012) 80-88, doi:10.1016/j.ijadhadh.2011.11.008 